\title{
PENGARUH LINGKUNGAN KERJA DAN PERILAKU PENGGUNAAN ALAT PELINDUNG DIRI TERHADAP KESEHATAN AWAK KAPAL IKAN TIPE POLE AND LINE
}

\author{
Monalisa Manuputty \\ monalisa_ftunpatti@yahoo.com \\ Fakultas Teknik Universitas Pattimura Ambon
}

\begin{abstract}
ABSTRAK
Lingkungan kerja di kapal dipengaruhi oleh faktor-faktor fisika seperti getaran, kebisingan dan suhu. Paparan dari getaran, kebisingan dan suhu yang dirasakan oleh awak kapal dapat mempengaruhi kesehatannya. Selain itu perilaku penggunaan alat pelindung diri yang mengikuti aturan dapat melindungi awak kapal dari paparan faktor-faktor tersebut. Penelitian ini bertujuan menganalisis pengaruh paparan pada lingkungan kerja dan perilaku penggunaan alat pelindung diri terhadap kessehatan awak kapal dalam hal ini kondisi tekanan darah, denyut jantung dan stress kerja. Responden dalam penelitian ini adalah awak kapal ikan tipe pole and line. Analisis data menggunakan Partial Least Square (PLS). Hasil analisis dengan nilai R square sebesar 0,685 menunjukkan bahwa lingkungan kerja dengan indikator getaran, kebisingan dan suhu serta perilaku penggunaan alat pelindung diri secara bersama mempengaruhi kesehatan awak kapal sebesar 68,5 \% dan 31,5\% dipengaruhi oleh faktor lain. Lingkungan kerja dengan indikator getaran, kebisingan dan suhu mempengaruhi kesehatan awak kapal sebesar 37\% sedangkan $63 \%$ dipengaruhi oleh faktor lain. Dengan nilai T-statistik 1,843>1,67 pada alpha 0,05, dapat dikatakan lingkungan kerja secara signifikan mempengaruhi kesehatan kerja. Perilaku penggunaan alat pelindung diri berupa pakaian kerja, sepatu kerja dan alat pelindung telinga mempengaruhi kesehatan awak kapal sebesar 58,4\% sedangkan 41,6\% dipengaruhi oleh faktor lain. Dengan nilai Tstatistik $1,712>1,67$ pada alpha 0,05 , dapat dikatakan perilaku penggunaan alat pelindung diri secara signifikan mempengaruhi kesehatan kerja.
\end{abstract}

Kata Kunci: lingkungan kerja, perilaku penggunaan APD, tekanan darah, denyut nadi, stress kerja

\section{PENDAHULUAN}

Badan kesehatan dunia (WHO) menempatkan faktor-faktor resiko pada lingkungan kerja pada urutan ke sepuluh penyebab terjadinya penyakit dan kematian. Penyakit akibat kerja adalah kondisi yang diakibatkan oleh paparan di tempat kerja yang disebabkan karena faktor fisika, kimia, biologi, ergonomi dan psikososial pada lingkungan kerja sejauh mekanisme fisiologis normal terpengaruh dan kesehatan pekerja terganggu. Secara internasional, sektor perikanan laut diakui sebagai tempat kerja yang paling berbahaya di seluruh dunia dan secara signifikan lebih tinggi menyebabkan kecelakaan dan penyakit bila dibandingkan dengan sektor lain seperti pertanian atau konstruksi. Pekerja di kapal penangkap ikan terpapar kondisi yang tidak menguntungkan seperti suhu yang panas atau dingin, kebisingan, getaran, mengangkat benda berat, jam kerja yang tidak menyenangkan dan panjang sehingga berdampak negatif pada kondisi kesehatan dan kinerja mereka (HSA, 2014).

Ada karakteristik unik tertentu atas kedudukan pelaut yang harus dipertimbangkan ketika mempelajari lingkungan kerja di atas kapal. Pekerjaan pelaut dan awak kapal secara keseluruhan banyak berbeda dari tempat kerja di daratan. Yang patut dipertimbangkan adalah kondisi fisik dari lingkungan kerja di kapal. Kapal adalah tempat kerja yang bergerak dan memiliki kondisi iklim panas atau dingin yang berdampak besar pada kondisi kerja. Selain itu, lingkungan kerja di kapal dipengaruhi juga oleh kebisingan dan getaran (Kristiansen, dalam Lang, 2011). Getaran mekanis yang dirasakan oleh awak kapal adalah getaran seluruh tubuh. Getaran intensif dengan frekuensi antara $4 \mathrm{~Hz}-11 \mathrm{~Hz}$ dapat menyebabkan peningkatan denyut jantung (Jegaden, 2013). Efek negatif pada kesehatan manusia yang diakibatkan oleh peningkatan kebisingan dapat diamati melalui efek fisiologis dan psikologis. Kerusakan organ pendengaran pada pelaut yang telah bekerja lebih dari empat tahun dapat dibuktikan melalui pemeriksaan medis. Selain itu, perubahan kenaikan tekanan darah sistolik, tekanan darah diastolik, tekanan arteri, tekanan nadi dan denyut jantung secara signifikan dipengaruhi oleh paparan kebisingan di 
tempat kerja (Singhal, et al 2009 dan Kalantary, et al 2015). Suhu yang tinggi antara lain dapat menyebabkan heat stress, heat stroke, ruam panas dan kelelahan panas. Kelelahan panas terjadi karena bekerja secara terus menerus di lingkungan yang panas yang menyebabkan dehidrasi sehingga volume sirkulasi darah ke organ vital seperti otak dan jantung menurun. Suhu inti tubuh mengalami kenaikan dan pekerja mengalami sakit kepala, denyut jantung cepat, mual, kelelahan hingga pingsan (Huss, et al., 2013). Miller, et al. (2016) menyatakan kadang-kadang pengaturan lingkungan kerja fisik seperti kebisingan, kurangnya privasi, pencahayaan yang buruk, ventilasi yang buruk, kurang baiknya pengontrolan suhu ruang kerja atau fasilitas sanitasi yang tidak memadai dapat menyebabkan stres.

Penggunaan alat pelindung diri merupakan salah satu cara yang dapat dilakukan untuk mengurangi atau menghilangkan efek negatif dari paparan faktor fisika dalam lingkungan kerja seperti getaran, suhu dan kebisingan. Selain itu setiap pekerja wajib mengetahui setiap bahaya yang akan ditemui di lingkungan kerjanya agar dapat mengantisipasi bahaya kerja yang akan dialami dan dalam bekerja harus mengikuti peraturanperaturan tentang keselamatan kerja (ILO, 2013).

Penelitian ini bertujuan melihat pengaruh getaran, kebisingan dan suhu pada lingkungan kerja di kapal ikan tipe pole and line dan perilaku penggunaan alat pelindung diri terhadap kesehatan awak kapal.

\section{KAJIAN TEORI DAN METODE}

\section{A. Kesehatan dan Lingkungan Kerja}

UU No 23 / 1992 Tentang kesehatan menyatakan "Keadaan sejahtera dari badan, jiwa dan sosial yang memungkinkan setiap orang hidup produktif secara sosial dan ekonomis" (KesMas, 2014).

Hendrik L. Blum menyatakan terdapat 4 faktor yang mempengaruhi derajat kesehatan manusia, yaitu: faktor perilaku, pelayanan kesehatan, keturunan dan lingkungan. (Mariam, 2015).

Menurut Undang-Undang No. 36 tahun 2009 Tentang Kesehatan, upaya kesehatan lingkungan ditujukan untuk mewujudkan kualitas lingkungan yang sehat baik fisik, kimia, biologi, maupun sosial yang memungkinkan setiap orang mencapai derajat kesehatan setinggi-tingginya. Lingkungan sehat tersebut antara lain mencakup lingkungan pemukiman, lingkungan kerja, tempat rekreasi serta tempat dan fasilitas umum (KesMas, 2014).

Istilah lingkungan kerja digunakan untuk menggambarkan kondisi di sekitar manusia saat manusia sebagai pekerja beroperasi. Menurut Undang-Undang No. 1 tahun 1970 tentang Keselamatan Kerja dan PP 55 tahun 2010 tentang Pembinaan dan Pengawasan Penyelenggaraan Pengelolaan Usaha Pertambangan Minerba: Lingkungan kerja ialah tiap ruangan atau lapangan, tertutup atau terbuka, bergerak atau tetap dimana tenaga kerja bekerja, atau yang sering dimasuki tenaga kerja untuk keperluan suatu kegiatan dan di mana terdapat sumber atau sumber-sumber bahaya dari lingkungan kerja berupa bahaya fisika, kimia, biologi, ergonomi, dan psikososial (Riadi, 2014). Secara umum terdapat 5 (lima) faktor bahaya di tempat kerja ditinjau dari aspek keselamatan dan kesehatan kerja, antara lain: faktor bahaya fisika, faktor bahaya biologi, faktor bahaya kimia, faktor bahaya biomekanik atau ergonomi serta faktor bahaya psikososial. Para pekerja dapat berhubungan dengan bahaya fisika, kimia, biologi, ergonomi dan psikososial pada saat melakukan tugas dan tanggung jawabnya (ILO, 2000).

\section{B. Lingkungan kerja di Kapal}

Kapal perikanan adalah salah satu tempat kerja yang beresiko tinggi terhadap keselamatan dan kesehatan awak kapal. Awak kapal pada kapal perikanan bekerja disemua kondisi laut yang tidak bersahabat, hujan, badai dan suhu yang esktrem, tidak ada jam kerja tetap dan irama kerja ditentukan oleh laut dan tangkapannya. Bahaya penyakit yang dialami oleh awak kapal pada kapal perikanan antara lain berasal dari faktor fisika yaitu getaran, kebisingan dan suhu, faktor kimia, faktor biologi dan faktor psikososial (ILO, 2014).

\section{Getaran di Kapal}

Getaran yang dirasakan di kapal disebabkan oleh putaran baling-baling, mesin utama dan mesin bantu serta kondisi laut (Carter \& Schreiner, 2014). Getaran yang timbul karena pengoperasian mesin-mesin dalam proses pekerjaan disebut getaran mekanis yang dapat menjadi sumber gangguan bagi anak buah kapal. Getaran mekanis yang dirasakan oleh anak buah kapal adalah getaran seluruh tubuh (whole body vibration) dihantarkan melalui bagian tubuh yang menopang 
seluruh tubuh seperti kaki pada saat berdiri di lantai yang bergetar. Di Indonesia, nilai ambang batas paparan getaran untuk kesehatan dan kenyamanan diatur oleh Keputusan Menteri Tenaga Kerja Nomor. PER.13/MEN/X/2011 tentang Nilai Ambang Batas Faktor Fisika dan Kimia di Tempat Kerja. NAB getaran yang kontak langsung maupun tidak langsung pada seluruh tubuh ditetapkan sebesar 0,5 meter per detik kuadrat $\left(\mathrm{m} / \mathrm{det}^{2}\right)$.

\section{Kebisingan di Kapal}

Kebisingan di kapal dihasilkan oleh mesin utama dan mesin bantu seperti generator listrik dan mesin tambahan untuk menggerakkan derek. Putaran baling-baling dan penggunaan sistem ventilasi juga menimbulkan kebisingan di kapal (Carter \& Schreiner, 2014). Efek utama dari paparan kebisingan terhadap pendengaran adalah kerusakan pendengaran mendadak oleh suara ledakan tiba-tiba yang sangat keras; tinnnitus atau telinga berdengung, gangguan pendengaran sementara dan gangguan pendengaran permanen. Gangguan non pendengaran termasuk stres, fisiologis dan perilaku. Pengaruh fisiologis antara lain: respon terhadap suara keras dimana otot menegang, irama pernafasan cenderung berubah ketika terpapar kebisingan, perubahan pola detak jantung, perubahan diameter pembuluh darah terutama di kulit. Konsekuensi lain dari paparan kebisingan yang berlebihan di tempat kerja termasuk gangguan komunikasi dan kinerja (HSE, 2015 \& OSHAnswers, 2015). Hampir semua negara merekomendasikan bahwa paparan kebisingan bagi semua pekerja harus dikendalikan di bawah tingkat $85 \mathrm{~dB}(\mathrm{~A})$ selama delapan jam dalam satu hari kerja untuk meminimalkan kerusakan atau gangguan pendengaran. Di Indonesia, nilai ambang batas paparan kebisingan adalah $85 \mathrm{~dB}(\mathrm{~A})$ diatur oleh Keputusan Menteri Tenaga Kerja Nomor. PER.13/MEN/X/2011 tentang Nilai Ambang Batas Faktor Fisika dan Kimia di Tempat Kerja.

\section{Suhu di Kapal}

Suhu panas dalam kamar mesin dihasilkan antara lain oleh pengoperasian mesin utama dan mesin bantu, pipa gas buang, generator, pipa uap, dan tangki pemanas bahan bakar (Serbanescu, 2016). Paparan suhu panas dapat menyebabkan masalah kesehatan dan dapat mempengaruhi kinerja. Pada saat suhu lingkungan meningkat, pekerja akan merasa stres dan mudah menjadi cepat marah, kehilangan konsentrasi dan kehilangan kemampuan untuk melakukan tugas-tugas yang terampil atau pekerjaan yang berat. Dalam lingkungan yang panas, tubuh berusaha untuk mempertahankan suhu normal, hal ini membuat denyut jantung meningkat untuk memompa lebih banyak darah ke bagian luar tubuh dan kulit sehingga terjadi keringat dan mengurangi kelebihan panas (NIOSH, 2016).

\section{Faktor Kesehatan 1. Denyut Nadi}

Denyut nadi adalah getaran/denyut darah di dalam pembuluh darah arteri akibat kontraksi ventrikel kiri jantung. Denyut nadi adalah frekuensi irama denyut/detak jantung yang dapat dipalpasi (diraba) dipermukaan kulit pada tempat-tempat tertentu. Tempat meraba denyut nadi adalah: pergelangan tangan bagian depan sebelah atas pangkal ibu jari tangan (Arteri radialis), dileher sebelah kiri/kanan depan otot sterno cleido mastoidues (Arteri carolis), dada sebelah kiri tepat di apex jantung (Arteri temparalis) dan di pelipis (Liana, 2012).

\section{Tekanan Darah}

Setiap detak jantung memompa darah dalam tubuh untuk menghasilkan energi dan mengedarkan oksigen. Pergerakan aliran darah ini menimbulkan tekanan yang menekan terhadap sisi dari pembuluh darah. Kekuatan atau tekanan untuk mendorong ini dikenal dengan tekanan darah. Terdapat 2 (dua) pengukuran penting dalam Tekanan darah, yaitu Tekanan Sistolik dan Tekanan Diastolik. Tekanan darah yang normal adalah berkisar antara $90 \mathrm{mmHg}$ sampai 119 $\mathrm{mmHg}$ untuk tekanan sistolik sedangkan untuk tekanan diastolik adalah sekitar $60 \mathrm{mmHg}$ sampai $79 \mathrm{mmHg}$. Tekanan darah dibawah 90/60 $\mathrm{mmHg}$ dikategorikan sebagai Hipotensi/Hypotension atau tekanan darah rendah, sedangkan di atas 140/90 $\mathrm{mmHg}$ sudah dikategorikan sebagai tekanan darah tinggi atau Hipertensi/Hypertension. (Dickson, 2016).

\section{Stres Kerja}

Taber's Cyclopedic Medical Dictionary dalam OSHAnswers (2012) mendefinisikan stres adalah hasil dari faktor-faktor emosional, fisik, sosial, ekonomi, dan lainnya yang memerlukan respon atau perubahan. Hal ini umumnya dipercaya bahwa beberapa stres adalah baik-baik saja 
(kadang-kadang disebut sebagai tantangan atau stres positif) tapi ketika stres terjadi dalam jumlah dimana pekerja tidak bisa menangani atau mengendalikannya maka dapat mengakibatkan perubahan baik mental maupun fisik. Beberapa tanda yang ditunjukkan ketika seseorang mengalami stres antara lain jantung berdebar, peningkatan tekanan darah, mengalami kecemasan, bermotivasi rendah dan mengalami kesulitan memecahkan masalah.

\section{METODE}

Penelitian observasional dengan desain penelitian cross-sectional. Penelitian dilakukan pada 7 buah kapal ikan tipe pole and line yang berada di desa Tulehu, Ambon. Jumlah responden ditentukan berdasarkan aturan dari analisis data yang digunakan dalam penelitian ini yaitu Partial Least Square (PLS) dihitung berdasarkan hasil kali jumlah indikator dengan faktor perkalian 5 yaitu 45 responden. Indikator dalam penelitian ini berjumlah 9. variabel laten eksogen lingkungan kerja dengan indikator getaran, suhu dan kebisingan. Variabel laten eksogen Perilaku dengan indikator penggunaan alat pelindung diri penggunaan baju kerja, sepatu kerja, pelindung telinga. Variabel laten endogen Kesehatan dengan indikator denyut nadi, tekanan darah, dan stres kerja. Jumlah responden dari masing-masing kapal ditentukan berdasarkan rumus proporsional random sampling.

Getaran kapal diukur dengan vibration meter, kebisingan diukur dengan sound level meter, suhu diukur dengan termometer suhu, denyut nadi dan tekanan darah diukur dengan sphygmo manometer. Stress kerja diukur dengan kuesioner stress kerja berdasarkan kriteria HARS (Hamilton Anxiety Rating Scale).

Hipotesis dalam penelitian ini adalah:

1. Ada pengaruh faktor lingkungan kerja terhadap faktor kesehatan (tekanan darah, denyut nadi, kondisi daya dengar, dan stres kerja).

2. Ada pengaruh faktor perilaku penggunaan alat pelindung diri terhadap faktor kesehatan

Berdasarkan variabel dan indikator yang telah ditentukan maka skema analisis data dibuat seperti pada gambar 1 .

\section{HASIL DAN PEMBAHASAN}

\section{A. Hasil Pengukuran}

Hasil rerata pengukuran tingkat getaran pada kamar mesin $1,1 \mathrm{~m} / \mathrm{det}^{2}$ sedangkan pada geladak kerja $0,6 \mathrm{~m} / \mathrm{det}^{2}$. Rerata kebisingan pada kamar mesin $89 \mathrm{~dB}$ dan pada geladak kerja $57 \mathrm{~dB}$. Rerata nilai suhu pada kamar mesin $33{ }^{\circ} \mathrm{C}$ dan 32 ${ }^{0} \mathrm{C}$ pada geladak kerja.

Berdasarkan hasil pemeriksaan tekanan darah terhadap 45 orang awak kapal diketahui 20 orang memiliki tekanan darah prehipertensi dengan nilai tekanan diastolik diantara $120-139 \mathrm{~mm} \mathrm{Hg}$ dan tekanan sistolik diantara $80-89 \mathrm{~mm} \mathrm{Hg}$. Tiga orang mengalami tekanan darah rendah dengan nilai tekanan diastolik $<90 \mathrm{~mm} \mathrm{Hg}$ dan tekanan sistolik $<60 \mathrm{~mm} \mathrm{Hg}$ dan 22 orang sisanya memiliki tekanan darah normal.

Hasil pengukuran denyut nadi mendapati seluruh responden memiliki denyut nadi yang normal dengan nilai diantara $60-100$ beats per minute. Berdasarkan hasil dari jawaban responden terhadap kuesioner stress kerja didapati 17 orang awak kapal merasakan stres akibat kerja dan 28 orang tidak mengalami stres kerja.

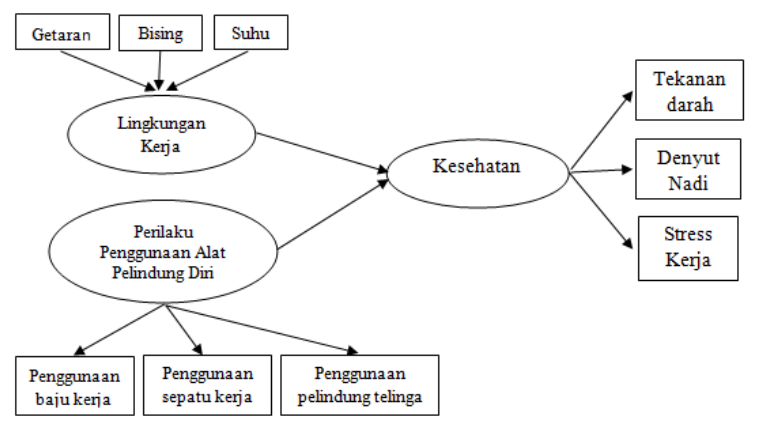

Gambar. 1.Skema Analisis Data

\section{B. Model Pengukuran / Outer Model dan Model Struktural / Inner Model}

Model pengukuran atau outer model dengan indikator refleksif dan formatif dievaluasi dengan convergent dan discriminant validity dari indikatornya dan composite reliability untuk blok indikator. Pengujian inner model terhadap model struktural dilakukan dengan melihat nilai Rsquare. Uji yang kedua melihat signifikansi nilai kooefisien paramater dan nilai signifikansi $t$ statistik.

Hasil uji outer model dengan memasukkan keseluruhan variabel nampak pada Gambar 2. Pada ketiga Variabel dengan indikatornya mempunyai nilai loading diatas 0,50 dan signifikan pada alpha 5\%, Semua konstruk dalam model yang diestimasi memenuhi kriteria discriminant validity, dalam model terlihat dari output pada tabel 1 dan tabel 2 . 
Tabel 1. Nilai Kontruks Reliability dan R Square

\begin{tabular}{|l|c|c|c|c|}
\hline & Nilai AVE & $\begin{array}{c}\text { Cronbach's } \\
\text { Alpha }\end{array}$ & $\begin{array}{c}\text { Composite } \\
\text { Reliability }\end{array}$ & R Square \\
\hline Kesehatan & 0,679 & 0,873 & 0,879 & 0,685 \\
\hline $\begin{array}{l}\text { Lingkungan } \\
\text { Kerja }\end{array}$ & 0,611 & 0,783 & 0,887 & \\
\hline Perilaku & 0,753 & 0,773 & 0,813 & \\
\hline
\end{tabular}

Tabel 2. Hasil Uji Hipotesis

\begin{tabular}{|l|c|c|c|c|}
\hline & $\begin{array}{c}\text { Original } \\
\text { Sampel }\end{array}$ & $\begin{array}{c}\text { Mean } \\
\text { Sampel }\end{array}$ & $\begin{array}{c}\text { Standar } \\
\text { Deviasi }\end{array}$ & T-statistik \\
\hline Lingk Kerja $\rightarrow$ Kesehatan & 0,370 & 0,365 & 0,201 & 1,843 \\
\hline Perilaku $\rightarrow$ Kesehatan & 0,584 & 0,389 & 0,341 & 1,712 \\
\hline
\end{tabular}

Dari tabel 1 diketahui data pada penelitian ini memiliki nilai reliabel yang tinggi yaitu $>0,8$. Pada variabel kesehatan nilai composite reliability 0,879 , variabel lingkungan kerja 0,887 dan variabel perilaku 0,813 . Dengan nilai $R$ square sebesar 0,685 menunjukkan bahwa lingkungan kerja dengan indikator getaran, kebisingan dan suhu serta perilaku penggunaan alat pelindung diri secara bersama mempengaruhi kesehatan awak kapal sebesar $68,5 \%$ dan $31,5 \quad \%$ dipengaruhi oleh faktor lain.

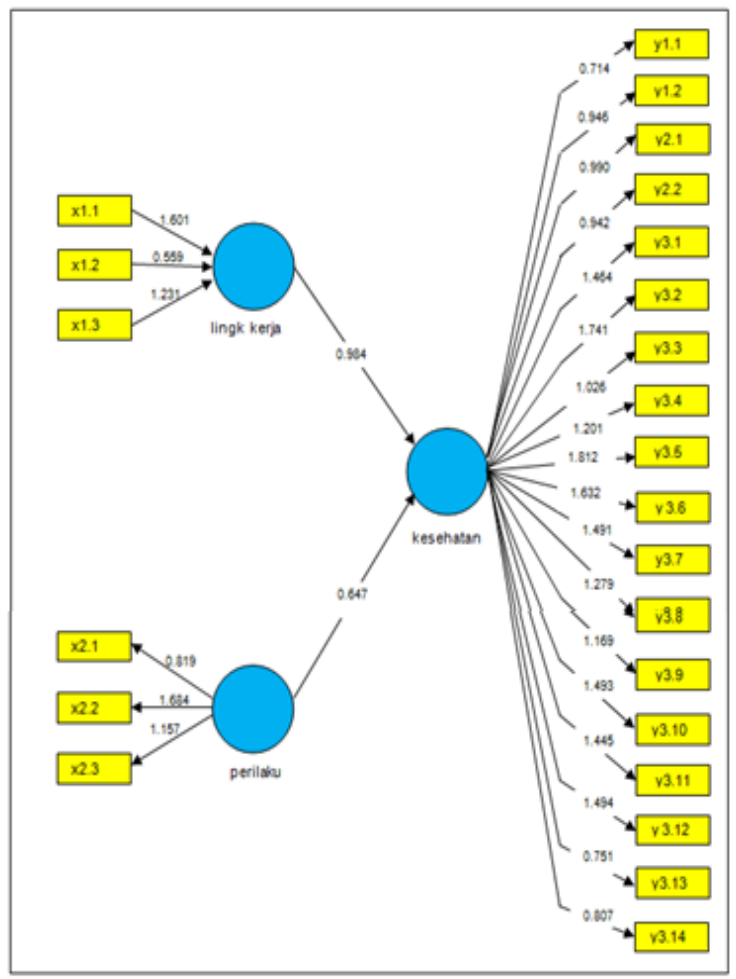

Gambar 2.

Berdasarkan hasil uji hipotesis dengan metode resampling Bootstrap diketahui variabel lingkungan kerja dengan indikator getaran, kebisingan dan suhu secara signifikan (T-statistik $>1,67$ pada alpha 0,05) mempengaruhi kesehatan sebesar 0,370. Begitu pula variabel Perilaku penggunaan alat pelindung diri secara signifikan mempengaruhi kesehatan sebesar 0,584.

\section{PEMBAHASAN}

Berdasarkan hasil pengukuran diketahui 20 orang awak kapal mengalami tekanan darah prehipertensi, bila hal ini dibiarkan maka akan mungkin awak kapal tersebut menjadi penderita hipertensi. Didapati pula 17 orang awak kapal merasakan stres akibat kerja. Berdasarkan hasil wawancara, para awak kapal merasakan bahwa lingkungan kerja sangat mempengaruhi kenyamanan saat bekerja sehingga bila lingkungan kerja buruk maka akan mempengaruhi tingkat stres yang mereka alami dan hal itu secara tidak langsung mempengaruhi tekanan darah. Selain itu paparan getaran, kebisingan dan suhu yang diterima oleh awak kapal saat bekerja juga mempengaruhi tekanan darah. Hal ini sesuai dengan penelitian yang dilakukan oleh Kumar, et al (2014) menyatakan tekanan darah mengalami peningkatan pada tingkat kebisingan di atas $70 \mathrm{~dB}$ sedangkan denyut nadi berada pada kisaran normal. Wang, et al (2013) menyatakan paparan kebisingan pada lingkungan kerja memiliki hubungan yang positif dengan hipertensi. Menurut Singhal, et al (2009) dan Kalantary, et al (2015) paparan kebisingan memberikan perubahan yang signifikan terhadap kenaikan tekanan darah sistolik, tekanan darah diastolik, tekanan arteri, tekanan nadi dan denyut jantung. Siagian (2012) meneliti tentang pengaruh getaran terhadap tekanan darah dan denyut nadi dan menyatakan bahwa paparan getaran meningkatkan tekanan darah dan denyut nadi. Semakin tinggi frekuensi getaran maka tekanan darah dan denyut nadi 
mengalami kenaikan. Suhu pada geladak kerja berada pada nilai $32{ }^{\circ} \mathrm{C}$ sedangkan nilai ambang batas utuk suhu di tempat kerja adalah $31{ }^{\circ} \mathrm{C}$ untuk pekerjaan ringan dan $27{ }^{\circ} \mathrm{C}$ untuk pekerjaan berat. Menurut Purwaningsih \& Aisyah (2016) temperatur lingkungan kerja yang panas berpengaruh terhadap perubahan denyut nadi pekerja. Berdasarkan hasil pemeriksaan, denyut nadi seluruh awak kapal yang menjadi responden berada pada kisaran normal.

Pada hasil uji hipotesis 1 yaitu lingkungan kerja mempengaruhi kesehatan, berdasarkan hasil yang didapat di ketahui lingkungan kerja dengan indikator getaran, kebisingan dan suhu mempengaruhi kesehatan awak kapal sebesar 37\% sedangkan $63 \%$ dipengaruhi oleh faktor lain. Dengan nilai T-statistik 1,843>1,67 pada alpha 0,05 , dapat dikatakan lingkungan kerja secara signifikan mempengaruhi kesehatan kerja. Sehingga lingkungan kerja harus diperhatikan secara baik agar paparan dari faktor-faktor pada lingkungan kerja yang melebihi nilai ambang batas harus dapat dikendalikan atau dikurangi sehingga kesehatan awak kapal tidak terganggu.

Hasil uji hipotesis 2 yaitu perilaku penggunaan alat pelindung diri mempengaruhi kesehatan, berdasarkan hasil yang didapat di ketahui perilaku penggunaan alat pelindung diri berupa pakaian kerja, sepatu kerja dan alat pelindung telinga mempengaruhi kesehatan awak kapal sebesar $58,4 \%$ sedangkan $41,6 \%$ dipengaruhi oleh faktor lain. Dengan nilai T-statistik $1,712>1,67$ pada alpha 0,05 , dapat dikatakan perilaku penggunaan alat pelindung diri secara signifikan mempengaruhi kesehatan kerja. Berdasarkan hasil penelitian Reinhold, et al, (2014) dan Setiyanto, (2013) penggunaan alat pelindung diri dapat mengurangi dampak dari paparan secara signifikan. Untuk itu pada saat bekerja awak kapal harus secara disiplin menggunakan alat-alat pelindung diri untuk mengurangi dampak dari paparan faktor-faktor lingkungan kerja seperti getaran, kebisingan dan suhu. Selain itu pengelola atau pemilik perusahaan harus menyediakan alat pelindung diri sesuai dengan lingkungan kerja dimana para awak kapal itu bekerja.

Perbaikan lingkungan kerja harus dilakukan bila nilai paparan faktor-faktor pada lingkungan kerja seperti getaran, kebisingan dan suhu telah melebihi ambang batas, untuk itu pengukuran lingkungan kerja harus dilakukan minimal 1 tahun sekali. Untuk mengetahui pengaruh faktor-faktor lingkungan kerja pada awak kapal, pemeriksaan kesehatan secara berkala harus selalu dilakukan minimal 6 bulan atau setahun sekali. Hal ini untuk melindungi awak kapal dari penyakit akibat kerja yang sifatnya komulatif atau semakin lama akan semakin parah bila tidak cepat diobati.

\section{KESIMPULAN}

1. Dengan nilai $\mathrm{R}$ square sebesar 0,685 menunjukkan bahwa lingkungan kerja dengan indikator getaran, kebisingan dan suhu serta perilaku penggunaan alat pelindung diri secara bersama mempengaruhi kesehatan awak kapal sebesar 68,5\% dan $31,5 \%$ dipengaruhi oleh faktor lain.

2. Lingkungan kerja dengan indikator getaran, kebisingan dan suhu mempengaruhi kesehatan awak kapal sebesar 37\% sedangkan $63 \%$ dipengaruhi oleh faktor lain. Dengan nilai T-statistik 1,843>1,67 pada alpha 0,05, dapat dikatakan lingkungan kerja secara signifikan mempengaruhi kesehatan kerja.

3. Perilaku penggunaan alat pelindung diri berupa pakaian kerja, sepatu kerja dan alat pelindung telinga mempengaruhi kesehatan awak kapal sebesar 58,4\% sedangkan 41,6\% dipengaruhi oleh faktor lain. Dengan nilai Tstatistik $1,712>1,67$ pada alpha 0,05 , dapat dikatakan perilaku penggunaan alat pelindung diri secara signifikan mempengaruhi kesehatan kerja.

\section{DAFTAR PUSTAKA}

ABS. 2012. Guide for Crew Habitability on Ships. Houston: American Bureau of Shipping.

Carter, T., \& Schreiner, A. 2014. 19.2 Vibration on Board Ships. Textbook of Maritime Medicine.

Tersedia: www.textbook.ncmm.no

HSE. 2015. Noise. Health and Safety Executive. Tersedia: www,hse.gov.uk

ILO. 2000. International Hazard Datasheets on Occupation. International Labour Organization. Tersedia: www.ilo.org

ILO. 2014. Safety and Health in The use of Chemicals in The Workplaces. International Labour Organization. Tersedia: http://www.ilo.org

Kalantary, S., Dehghani, A., Yekaninejad, M. S., \& Omidi, L. 2015. The Effects of Occupational Noise on Blood Pressure and Heart Rate of Workers in an Automotive Parts Industry. ARYA Atheroscler; Volume 11; Issue 4, p215-219. 
KesMas. 2014. Pengertian kesehatan Lingkungan. Public Health Home. Tersedia:www.indonesian-publichealth. com

Kumar, P., Saran, V., \& Harsha, S., 2014. "Effect of Noise and Vibration on Human Physiological Parameters". In MIT International Journal of Mechanical Engineering, Vol. 4, No. 1: p58-62.

Liana, M., 2012. Pengukuran Denyut Nadi. Tersedia blogspot.co.id

Mariam, I. 2015. Antropologi dan Sosiologi kesehatan Sosial dan Budaya. Slideshare. Tersedia: http://www. slideshare.net

NIOSH, 2016. "Heat Stress - Heat Related Illness", Centers for Disease Control and Prevention; U.S. Department of Health \& Human Services. Tersedia: www.cdc.gov/niosh

OSH Answers. 2015. Control Strategies for Workplaces. Canadian Centre for Occupational Health \& Safety. Tersedia: http://www.ccohs.ca

Purwaningsih, R., \& Aisyah. 2016. Analisis Pengaruh Temperatur Lingkungan, Berat Badan dan Tingkat Beban Kerja Terhadap Denyut Nadi Pekerja Ground Handling Bandara. Jurnal Teknik Industri, p15-20.

Reinhold, K., Kalle, S., \& Paju, J. 2014. Exposure to High or Low Frequency Noise at Workplaces: Differences Between Assessment, Health Complaints and
Implementation of Adequate Personal Protective Equipment. Agronomy Research, p895-906.

Serbanescu, I.. 2016. Consideration Regarding Maritime Ship Engine Room Ventilation System. International Journal of Innovative Research in Engineering \& Management (IJIREM) ISSN: 2350-0557, Volume-3, Issue-1.

Setiyanto, T., 2013. "Pengaruh Intensitas Kebisingan Terhadap Kenaikan Denyut Nadi Pada Pekerja di PT. Pertani (Persero) Cabang Surakarta. Tersedia: www.eprints.ums.ac.id

Siagian, M. 2012. Aircraft vibration and other factors related to high systolic blood pressure in Indonesian Air Force pilots. Health Science Indonesia, p27-33.

Singhal, S., Yadav, B., Hashmi, S., \& Muzammil, M. 2009. Effects of Workplace Noise on Blood Pressure and Heart Rate. Biomedical Research, p122-126.

Wang, S., Qin, Q., Liu, L., Han, L., \& Chen, Y. 2013. A Cross-Sectional Study on The Effects of Occupational Noise Exposure on Hypertension or Cardiovascular Among Workers from Automobile Manufacturing Company of Chongqing, China. J. Biomedical Science and Engineering, p1137-1142.

WWF. 2015. Perikanan Cakalang dengan Pancing Huhate. Jakarta. WWF-Indonesia. 